\title{
犬の輸血と輸液についてその 2
}

北

前節に述べたように大の臨床において発現するショッ クや低蛋白症, 低蛋白血症などに陥ったものの治療処置 として全血輸血は極めて効果的であることは十分認めら れるところであるが，さてこれを実際に行ならためには その操作はすべて絶対無菌的にしなければならないし， また一方人の場合のごとく常時保存血液を備兄て置くた めの施設，あるいは血液銀行の上うな制度もなければな らないのでわが国の現況に打いては犬の場合はなかな か困難であることはご承知の通りである，そこでこれに 代るものとして健康な採血用犬を常時繋養して，これか ら必要の都度採血して注輸することになるが，その際に もまた輸血技術の習熟, 輸血設備の完備, 器具なぞの用 意も十分でなければならないので臨床家にとってもいさ さか厄介で実施は容易ではなく実地応用性子薄い。

元来生体がショック状態に陷ると先ず第 1 亿体中の循 環血液量が急激に減少して血管床容積とその中を流孔る 流血量がどんどん懸隔した状態になり血圧は当然低下し て来る. 一方また冠血流量や 4 肢および重要臓器への血 流量も減少し，脈搏は頻数を示すにもかかわらず心送血 量は減少して体内の各組織への無酸素状態が招 来され る. その結果心機能は減弱し, また毒性物質をも生じて 血管の透過性は高まり, ますます循環血液量の減少は著 明になって来て血流は緩徐となって悪循環を形成し, 遂 には不可逆ショックを呈して死を招来するに至るのであ る. しかしこのような場合に時期を失せずに直ちに外か ら血液もしくはこれに代る有効成分を含んだ補液類の注 輸があれば循環血液量は急速に増加して, 組織の血流 量, 之くに冠血流量, 脳血流量が回復し, 心機能は正常 に戻り無酸素状態は回復し, 生体は正常の機能を取り戻 すことができる．しかしショックの成因のうち失血のみ がその原因と見られる場合は必らずしも全血輸血を行な わなくても, リンゲル氏液, または食塩水のような晶質 液, あるいはブドウ糖液のような栄養液の注輸を行なう ことによっても一時的に循環血液量を増大して危機を脱 れることができる.しかしこのような溶液は永く血管内 に止まらないで短時間に血管外に漏出して再び循環血液 量の減少をきたすから，この際は全血輸血を行なら必要 がある.もしこの際血漿あるいは代用血漿刘のごとき膠 質液を注輸するならば, 前記の晶質液に比べて遙かに長 時間血管内にとどをり血圧の低下を防ぐことができるの で非常に効果的となるのである。また出血のごときでは

* 麻布獣医科大学

日獣会誌

15 (1962)

\section{昂*}

ない血管元性ショックとか神経元性ショックのような場 合は実施に面倒な全血輸血を行なわなくても, 膠質液の 1つである血漿や代用血漿などの注輸で十分にその目的 を達せられることは, ショックの病態生理から見ても理 解されるところである.

通常概括的にいって輸液と称する場合は晶質液である 生理的電解質溶液と栄養液（糖液や必要な栄盖素を含九 だ溶液）または膠質液である血漿液，代用血漿液などの 注輸を指するのであり,さらに脱水状態に対処して水分 の補給を必要とする場合にも広い意味において輸液は行 なわれるが，水分単独だけの補給は通常行なわれず電解 質や血漿などの補給の際に必要の水分必合併して注輸さ れる場合が多い。こでは輸液として臨床上重要意義を もつ血漿 (プラズマ) 輸夜について述べることとする.

\section{1. 犬のプラズマ輸液について}

血獎輸液に対し全血輸血の効果はもっぱらそのうちに 赤血球を含むことに意義があることは当然であるが，急 性失血のごとき場合に拈いてすらもな拈循環血液量の補 充という点に注目すれば緊急使用のためには先ず取り敢 えず血漿を注輸し，しかる後に全血輸血を行なって十分 に生命を取り留めることができるといら事実に基いて急 性失血の死因となるものは血球の亡失よりもむしろ血獎 の喪失の方が遙かに重大意義があることが判る。このよ らなことから臨床上血漿輸液が犬に対しどのような効果 があるかを検討して見ると，第 1 には血液量が急激に減 少した際，体組織から必要な蛋白を補給するのには相当 な時間を要するが血漿，または全血を注輸すれば所要の 蛋白は直ちに増加してくる．とくに血槳は血液型を問わ ず直ちに使用できること緊急注輸できる利点がある.

第 2 には低蛋白症のごとく慢性的な蛋白不足状態のもの に対し完全に利用することのできる不足分の各種の蛋白 を補給し代謝機能を促進できる. 第 3 亿は輸血事故が絶 対㲹起こら始安全に注輸でき, 血液凝固に必要な成分 とか, とくに必要とする蛋白成分, 例えばアルブミン欠 そのものにはそれを補うことができ，一部では細菌やウ イルスなどその抗体を供給するような効果もあることが 認められている.このようにして血漿輸液の効果は臨床 的に応用して極めて価值の高いものがあることが認めら れるようになった。

\section{2. 犬の乾燥プラズマ (血漿) について}

Moon (1938), や Strumia (1937) のショックおよ びこれに関連した毛細管現象, 血漿蛋白の血管外逸出に 
関する理論や，BLALOCK (1940) のショックと循環系内 血嶈総量の関係が明らかにされ，さらに ELLIOT や STRUMIA（1940）らによって血漿の治療価值とその応用が 確立されて人医界に新いては赤血球をもたない血漿が全 血と同じ効果をもつことが実証され，折りから勃発した 第 2 次世界大戦の影響も西ってこのような血漿を長期に 亘って安全に保存し翰送に便利なようにする工夫が研究 され，乾燥ジフテリア血清のごとき方法をもって血漿を 取り扱い得るや否や汇ついて米国のFlosdorf and Mudd 学派の研究が深かく真剣に行なわれて来たが，遂いに凍 結真空乾燥法によって血嶈を乾燥し，その大量生産化に 成功して人医界注今日の乾燥プラズマ利用の盛大さをも たらしたのである.わが国においても戦後米国よりこの 技術を導入してプラズマはもちろんその他血清類, 精液 など保存に便であって, しかも必要に応じ使用に際し溶 媒飞対し高度の溶解性を保たしめる方法として各方面に 活用されるに至った。

著者らは犬の全血輸血の必要性が確認されているにも かかわらず実際にはその実施が困難であること，および これに代るものとして血漿輸液の効果が著明であること に注目して血漿の安定性を保ち, 使用簡便で, かつ携行 飞便利であり,な挑用に当ってもその濃度を自由に 調製できる犬の乾燥プラズマの製造について研究し, 遂 い深日本生物科学研究所の協力を得て成功するに至った (写真 1).

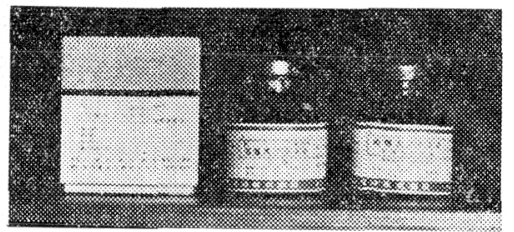

写真 1

\section{3. 乾燥プラズマ製造の概略}

健康な採血用犬を選択し採血隹当っては $6 \%$ チトラー 卜液を採血量の $8 \%$ 添加して採血し，これを泠室内に 1 昼夜放置しその上層部にできる血嶈を分離し，これを減 菌瓶汇分注しー $20^{\circ} \mathrm{C}$ で泠室で涷結したものをさらに凍結 乾燥器にか汗て製品としたものである。この製造過程に おいて最も考虑を払った点は原料である血漿の安全性と その蛋白成分の変化防止についてであって, 前者につい ては臨㦿検查を戦密に行なって健康な採血犬の選抧汇努 め, とくに肝炎, レプトスピーラー症, ジステンパー症 などの血液混入防止に留意し特殊の減菌処理を行ない凍 結乾燥したものであって, 一方また乾燥プラズマの主体 成分で市る蛋白質の成分については製造過程の操作中に 物ける変化の発現の有無に注目したが, 乾燥プラズマの 蛋白成分をチゼリコースにより分劃を見ると，第 1 図の ごとく犬生血漿にほぼ近いものを示し，僅かにアルブミ ンが変化している程度であって製造過程中の処理によっ
第 1 図 Plasma の電気泳動図

正常犬血漿

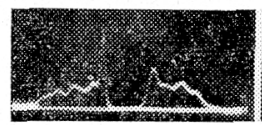

Asc $\rightarrow$
乾燥犬プラズマ

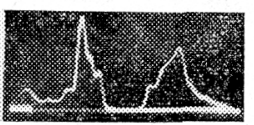

$\leftarrow$ Des

て蛋白成分に大きな变化浔認られないし，またこのよ らにして製造された乾燥プラズマを用いて犬に対する生 体実験においても血液性状拈よび臨床症状から観察して も良好な成績を示し，肝機能を蹯害せず尿中にも蛋白の 排泄は認められなかったし，一方またこのプラズマによ る血漿置換試験の結果は蛋白分履には24時間ないし48時 間を経過して一時乾燥プラズマのパターンに近かったも のも正常に復するのを見た。従って輸液された乾燥プラ ズマは比較的早く血中より消失して, 他の貯蔵蛋白ある いは組織蛋白と入れ代るか，あるいは肝を通過する際に 速か飞再成されるものと考党られる。

\section{4. 乾燥プラズマの輸液法}

\section{1) 輸液用具}

犬に対するプラズマの大量輸液を行ならために便利な ものと, 写真 2 小よび写真 3 に示すよらな輸液セットを 考案した。実施に際してはこれらの器具を用いて点滴輸 液を行なら方法が最も安全に実施できるのであって，小 量輸液の際は適当な注射器を用いて直接静脈（膊, サ> エーナなどの静脈) 内に注輸することも差支光ないが， 注入速度はとくに留意して常に一定の速度で行なうょう に心懸けな补ればならない。プラズマの溶解には添付し てある溶解液を使用し, 蒸溜水やリンゲル氏液などを用 いると凝集を来たすこともあるので，これは絶刘に避け なければならない。

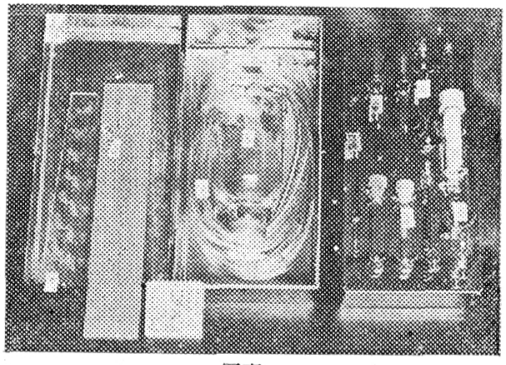

1. 沪過管

真 2

2. 輸液針, 翰血釬, 採血針 血液型検查用採沮管

同ピペット

6. 輸液瓶 (翰血兼用)

4.

$$
\text { 问 }
$$

7. 輸液用ビニール管(業血㒸用)

8. 䀷固定板

9. 血液型唡查用ホール板

\section{2) 輸液手技}

輸液瓶による点滴輸液, あるいは注射器による直接注 輸のいずれの場合でも犬の保定, 操作の確実さからいっ て前膊静脈を使用することが最も望ましい，写真4のご とく保定板飞前肢を確実に保定し，さらに輸液針を䋛創 膏で留めて保定する。静脈内への針の刺入经確実に行な 


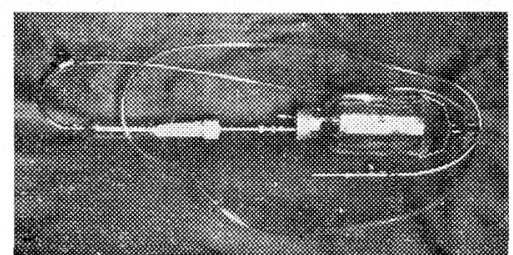

写真 3

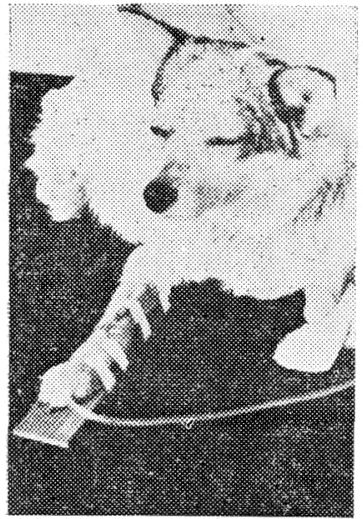

写真 4
ら必要があり，脈管の所在 が不明の場合は切開露出の ら光刺入して差支えない。 点滴輸液の場合のごとく比 較的長時間を要する場合は ポリテン管を用いて注輸状 沉を確認しつつ行ならこと がよい(写真 5$)$. 万一脈管 刺入が困難な場合に亦って は皮下，あるい:腹腔内な ぞへプラズマ注輸军行なっ て子十分吸收されるが速効 的効果を期待するならば脈 管刺入の方が良好である。

\section{3）輸液速度已輸液量}

血漿輸液を行なら目的の重要な ものの1つと乙て㡒環血液量の減 少に伴なら血压の低下を来たした 場合が多いが，このように血圧の 低下が著明に見られるものの場合 は輸液を急速度に行なって血圧を 先ず正常值に戻すことが先決であ るが，一般にはでき得る限り緩徐 な速度で注輸する方がよい。通例 低蛋白症など血压に変化の少なく ないものに対しては点滴注輸では 扣扮む权 $10 \mathrm{cc} / 5$ ～10分程度の割合 で行ならのが適当な速度である。 また注輸されるべきプラズマの温

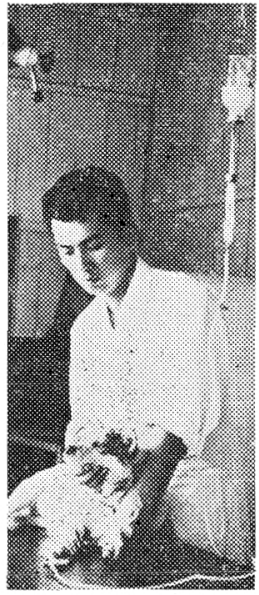

写真 5 度は常温（室温）で差支えない。これに温度を加えて温 めることは上記の速度で注輸される場合は不必要であ 万。

プラズマの輸液量の問題は1つに患犬の症状によって 決定されるべきもので一概には規定できないが，ショッ ク療法のごとき場合に执いては，例壳ば体重 $8.0 \mathrm{~kg}$ の犬 で約 $240 \mathrm{cc} の$ 失血によって血元性ショックを起こし, 最 高血压 $170 \mathrm{mmHg}$, 最低血压 $30 \mathrm{mmHg}$ のりが最高血 压 $120 \mathrm{mmHg}$ に下り, 最低血压 $60 \mathrm{mmHg}$ に上昇した

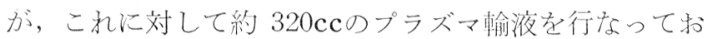
扰导权1時間後に洫圧は注添回復の状態走示してい る。享た失血療法に使用寸る場合はその出血量を各種の 補助診断法によって概算し失血量に相当する为のと考光
られるプラズマ量の注輸が必要であり，低蛋白症では血 中の総蛋白量を測定して不足分に相当するプラズマ量を 注輸すべきである。

\section{5. 乾燥プラズマ翰液適応症診断用臨床検査}

乾燥プラズマ輸液を必要とするものと考えられる患犬 に対し翰液実施前に臨床検査はできうる限り綿密に行な う必要加市る。一般検査の項目として, 一般状態, 栄 養, 元気, 食欲, 動作, 可視粘膜, 結膜, 心機能, 体温, 脈搏，呼吸などを，血液検査としては赤，白血球の異 動, 血色素指数の变動, 赤血球沈降速度, ヘマトクリッ ト值の測定などであり,さらに肝機能検查, 尿検査など は必らず行ならべきである。乙かしプラズマ輸液適応症 例として考㝋られるショック，貧血，低蛋白症などの場

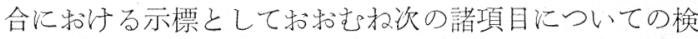
查をとくに重視しこれによって輸液を行なら。

\section{1) ヘマトクリット (Ht) 值の測定}

循環血液に血液濃縮現象や希血現象が現われていると きそそのへマトクリット值を測定しこれらの現象の程度 を判定する。このことは一面に拈いて翰血量や輸血速度 の決定のための補助䛦断にもなる。通常大の Ht 值の正 常值は 5.0 (4.0〜6.0) であって濃縮の場合はこの值は 高まる。

2) 血圧測定

前述のごとくショック発現の示標として血压の変化は
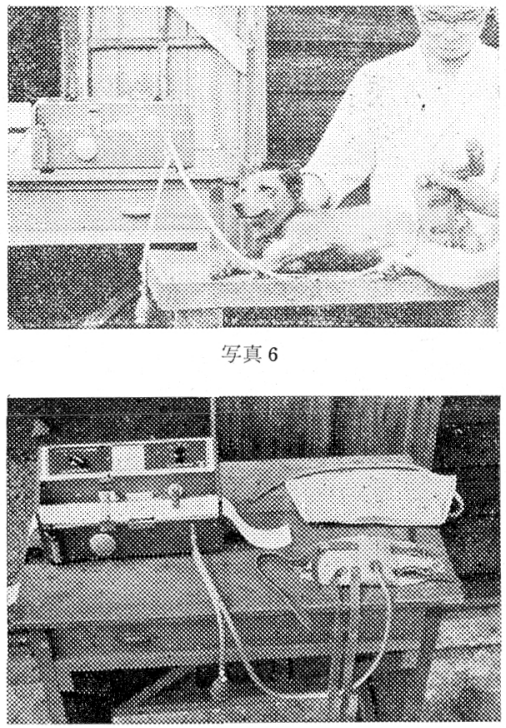

写真 7

重大な意義をもっているのであるが小動物，とくに犬の 血圧を間接的に簡単に測定することは困難であったが， 著者らはの方で使用している自動記録式脈波血圧計圭 犬用に改良して，とくにマンシェットに工夫を施して股 動脈部で容易に測定し得るようにした(写真 6,7 )。この 血圧計では最高血圧，中間血圧，最低血圧を測定し得る

日獣会誌 15 (1962) 
第 2 図 犬 Plasma 輸液例 $(100 \%)$ 推定年令 1 才 古 体重 $8.0 \mathrm{~kg}$ 採血量 $240 \mathrm{cc} \quad \mathrm{P}$-注入量 $320 \mathrm{cc}$

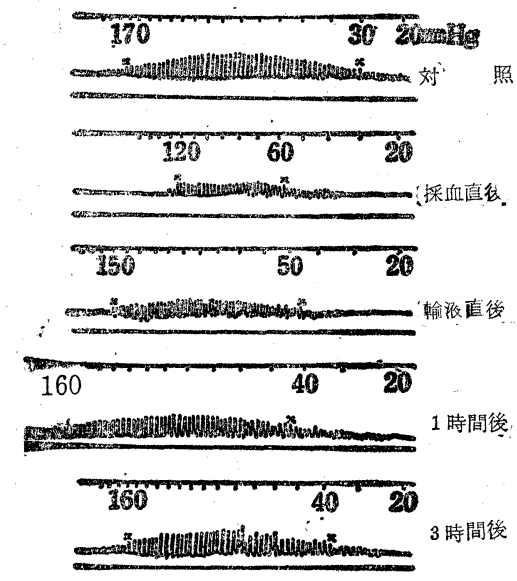

と同時に脈搏の状態も観察できるので臨床上にもその応 用性大である. 本器で測定した犬の正常血圧は大体平均 血圧で $140 \sim 180 \mathrm{mmHg}$ で, $200 \mathrm{mmHg}$ 以上のものある いは $100 \mathrm{mmHg}$ 以下のものは異常と見て差支えない(第 2 図).

\section{3）血液, 血漿の比重測定}

低蛋白症の診断法として簡単に示標の得られる方法と して血液，血漿の比重を測定するのであって普通硫酸銅 法を用いている. 此重を 1.020 1.060 までの段階で調 製しておくといずれの場合でも使用できる。犬に和忷る 血漿比重は 1.023 1.028 程度が正常值とされ，1.020 以下では低蛋白症，また全血では 1.050 以下では貧血症 拉よび低蛋白血症と見做される。

\section{4）血中蛋白の測定}

血中蛋白の量を知るための方法としては種々あるが， 臨床的に最も簡便な方法としては蛋白計を用いて測定す るのがよい．これは測定材料が少なくてすみ, 一定の光 線で目盛を読めば $1 \mathrm{dl}$ 中の蛋白濃度が算出される。通 常犬では 6.0〜 7.0 g/dl を正常値としている.

\section{6. 各種疾病に対する乾燥プラズマ輸液の臨床応用に} つレて

通常生体はその体内の蛋白の動きに関し血漿蛋白と組 織蛋白との間に密接な動的な平衡が保たれていて血漿蛋 白は血流の内外拈よび細胞の内外を出入して常に正常の 濃度を維持しょうとしてる. この平衡が出血や各種ショ ックあるいは疾患によって維持できなくなったとき，す。 なわち平衡が破れたときは組織蛋白, ひいては血漿蛋白 の喪失は著明であって他からの補給を必要とするに至る
のである.プラズマ輸液の効果はこの際に著明となるこ とが考えられる.

次にプラズマ輸液の対象となる疾患の主なるものを挙 げて見る。

\section{1）肝硬変, ネフローゼによる低蛋白症}

肝硬変および肝機能の低下するよらな状態にあるとき 肝細胞の代謝は悪化し, 肝に和ける蛋白の合成ならびに 再生機能は低下し低アルブミン血症を発現寸る。またネ フローゼでは腎の排泄機構は破壊されて, 血液中の蛋白 が㽷中に排浛されて, 血中蛋白が損失して低アルブミン 血症となる。このよらな場合に拈けるプラズマ輸液の効 果は組織に親和性をもつ蛋白を補給し, 肝細胞の蛋白代 謝機能に活性を与え, 組織蛋白あるいは貯臓蛋白を増加 させ，ひいては低蛋白症あるいは低蛋白血症を好転させ ることになる。

\section{2）手術侵襲による低蛋白症}

外科手術に执いては当然出血を伴ならから低蛋白血症 の発現は避け得ないところであるが，また同時:手術侵 襲によって組織蛋白の代謝も異常を示して低蛋白症をき たすものとされている：また生体の蛋白総量が低下して いるときは創傷の治癒機転は遅延する傾向を示すもので あって，このような場合にはプラズマ輸液は単に失血量 に対する循環血液量の補給のみならず, 組織代謝の円滑 化と創傷治癒の促進に寄与するところが大である.

\section{3）消化器疾患飞よる低蛋白症}

一般に消化器系統の疾患に沶いてはその大部分が食欲 の減退を示したり，または採食を廃絶するため必要の蛋 白摂取が不可能になるとともに嘔吐や下疮を伴なら場合 が多く, これがため腸管からの必要アミノ酸の吸収も低 下して血中の蛋白は減少し，同時に水分や電解質も喪失 不足し,さらに病状を悪化させることが多い。このよう な場合にプラズマ翰液は消化管は通さずに直接血中の蛋 白を増加させることになり, 同時に水分や電解質も併せ て補給されることになるので, 病状は好転させるし, 腸 蠕動をも六進するので食欲も増進するよらになる.

\section{4）食慨性, 伝染性疾患による低蛋白症}

飼料中の栄養素が不足したり，あるいは不十分であっ て蛋白筫の絶対量が不足した場合，あるいは伝染性疾患 などで飲食の廃絶と同時に, 発熱や炎症のため急速に低 蛋白症，あるいは低蛋白血症が引き起こされるが，とく に低蛋白血症では全身衰弱が強く現われ，急速に㔻白の 補給を必要とするが, このような場合にブラズマ輸液の 効果は急速に血中蛋白を堛加することができるので良成 績を収める。

\section{5）寄生虫症汇よる低蛋白症}

寄生虫の侵入を蒙ってしばしば著明な貣血があらわれ るが，この祭同時に貯藏蛋白，組織蛋白，血中蛋白も減 少して低蛋白症を示すようになる，とくに心臓系状虫症 
などにおいては腹水，あるいは浮腫を呈するものでは低 蛋白症は著明である．通常このような場合には全血輸血 が有効とされているが，低蛋白症を現わしたものでは， むしろプラズマ輸液の方が全血輸血よりも一層効果的で あって，とくに腹水や浮腫の認められるときはプラズマ 注輸量に扮いてその濃度を高めて輸液すると蛋白の補給 は無諭, 組織よりの脱水に対する効果も発揮して病性を 好転さすことができる。

\section{6）各種ショックに対す処置用}

すでに述べたごとくショックの病態生理は極めて複雑 であるが単一のショックとして起こらず, 実際には神経 元性, 血元性, 血管元性あるいは心臟元性のショックが それぞれ複合して起こる場合が多い。しかもショックを 起こす原因は血球が失われるためではなくて，血漿が減 少するためであって，一方またこのような場合循環血液 量の減少によって血圧の急激な低下も併行し重篤な症状 を示すのであるから，血管漏出性のない膠質液としての プラズマを注輸すれば，静脈環流を充実してショックか ら回復さすことも可能となってくるのである. 従ってこ のような際に血管透過性である晶質液（リンゲル氏液， 生食液, 糖液) の補給は単なる対症療法としての効果を 示すに過ぎないまたプラズマの主体は蛋白質であり， しかもアルブミンその他有効な必須アミノ酸に変り得る 各種蛋白が含まれているので, プラズマ輸液の効果はこ れらの補給といら意味においても十分効果的である.

：以上の観点に基いて実際に著者らがプラズマ輸液を行 なった症例についてその成績の概要を示すと第 1 表のご とくであって，外科的疾患では卵巣割去手術招よび盲腸 摘出術のような比較的出血や手術侵襲の少ない例ではと くに輸液の効果を認めることはなかったが，断脚術，ポ リープ, 骨折などのように出血や手術侵襲の大きいもの ほどプラズマ輸液の効果は著明に認められた。また内科 疾患では奇生虫症で著明な貧血を呈するものではその効
第 1 表

\begin{tabular}{|c|c|c|c|c|}
\hline \multirow{2}{*}{\multicolumn{2}{|c|}{ 疾 病 種 類 }} & \multicolumn{2}{|c|}{ 例 } & \multirow[b]{2}{*}{ 計 } \\
\hline & & $\begin{array}{l}\text { プラズマ } \\
\text { 輸液効果 } \\
\text { の顕著な } \\
\text { もの }\end{array}$ & $\begin{array}{l}\text { とくにプラズ } \\
\text { マ輸液効果が } \\
\text { あったと考学 } \\
\text { られないもの }\end{array}$ & \\
\hline \multirow{13}{*}{$\begin{array}{l}\text { 外 } \\
\text { 科 } \\
\text { 的 } \\
\text { 疾 } \\
\text { 患 }\end{array}$} & 盲腸 摘 出手術 & 4 & 8 & 12 \\
\hline & 断 脚 術 & 8 & 0 & 8 \\
\hline & 卵 覓 割 去 術 & 8 & 15 & 23 \\
\hline & 胃内異物摘出術 & 12 & 6 & 18 \\
\hline & ポリープ手術 & 20 & 2 & 22 \\
\hline & 骨 折 手 術 & 13 & 0 & 13 \\
\hline & 竐 & 65 & 31 & 96 \\
\hline & 混合性ショック & 15 & 0 & 15 \\
\hline & 低 蛋 白 症 & 18 & 0 & 18 \\
\hline & 栄蜜失調症 & 21 & 0 & 21 \\
\hline & 奇 生 虫 病 & 5 & 3 & 8 \\
\hline & 食 欲 不振 & 28 & 4 & 32 \\
\hline & 計 & 87 & 7 & 94 \\
\hline
\end{tabular}

果を認めたものが 8 例中 5 例であって比較的少なかった が，低蛋白症，栄養失調症などに対しては著明な输液効 果が認められた。また各種の臨床例の若干のものに対す るプラズマ翰夜前後の臨床症状を比較して見ると第 2 表 のごとくであって, 肝硬変, 低栄養, 消化器病など内科 的疾患では 1 回のプラズマ注輸量を比較的少なくして, これを長期間連続投与することによってょく血中蛋白を 回復させ臨床症状を好転さすことができ，骨折，ショッ ク，出血など外科的な疾患では初回の輸液量を多く，血 圧降下の度合に応じて急速に輸液して血圧の回復を先ず 図るとその効果も著明である。

\section{7. プラズマ輸液の副反応につレて}

乾燥プラズマの輸夜を行なった際に㧳ける副反応はそ の使用方法が適正であ机ば，実際には注とんどその発現

第 2 表
(日生研便り)

\begin{tabular}{|c|c|c|c|c|c|c|}
\hline 体重 & 年令 & 病 & 名 & プラズマ輸液前臨床症状 & プラズマ輸液量 & プラズマ輸液後の臨床症状 \\
\hline $12.0 \mathrm{~kg}$ & 3才 & 肝 硬 & 変 & $\begin{array}{l}\text { 食欲不振, 栄養不良, 肝機能障害 (卅) } \\
\text { 等血清蛋白 } 4.8 \mathrm{~g} / \mathrm{dl}\end{array}$ & $\begin{array}{l}1 \text { 日80 cc } 12 \text { 日間 } \\
\text { 計 } 960 \mathrm{cc}\end{array}$ & $\begin{array}{l}\text { 食欲増進, 栄養好転, 肝機能障害 }(+) \text {, } \\
\text { 蛋白 }(+) \text { 血清蛋白 } 5.2 \mathrm{~g} / \mathrm{dl}\end{array}$ \\
\hline 5.2 & 2 & 低 栄 & 養 & $\begin{array}{l}\text { 栄荃極度に不良, (やせ), 軽度の全 } \\
\text { 身性浮腫, 血清蛋白 } 4 \mathrm{~g} / \mathrm{dl}\end{array}$ & $\begin{array}{l}1 \text { 日 } 40 \mathrm{cc} 10 \text { 日間 } \\
\text { 計 } 400 \mathrm{cc}\end{array}$ & $\begin{array}{l}\text { 食欲増進, 栄養好転, 浮腫消失, 血 } \\
\text { 清蛋 } 6.2 \mathrm{~g} / \mathrm{dl}\end{array}$ \\
\hline 12.2 & 2 & 消化器 & & $\begin{array}{l}\text { 下㿑, 食欲不振, 湢吐, 軽度の浮腫, } \\
\text { 血清蛋白 } 6.3 \mathrm{~g} / \mathrm{dl}\end{array}$ & $\begin{array}{l}1 \text { 日 } 40 \mathrm{cc} 6 \text { 日間 } \\
\text { 計 } 240 \mathrm{cc}\end{array}$ & $\begin{array}{l}\text { 食欲増進, 下峲消失, 浮腫消失, 血 } \\
\text { 清蛋白 } 6.3 \mathrm{~g} / \mathrm{dl}\end{array}$ \\
\hline 7.2 & 1 & 寄生虫 & & $\begin{array}{l}\text { 栄養不良, 貧血, 脱力, 浮腫, 血清 } \\
5.9 \mathrm{~g} / \mathrm{dl}\end{array}$ & $\begin{array}{l}1 \text { 日 } 40 \mathrm{cc} 6 \text { 日間 } \\
\text { 計 } 240 \mathrm{cc}\end{array}$ & $\begin{array}{l}\text { 栄養好転，体力増強，血清蛋白 } \\
6.1 \mathrm{~g} / \mathrm{dl}\end{array}$ \\
\hline 8.0 & 2 & 骨 & 折 & $\begin{array}{l}\text { 自動車衝突による右前肢骨折, 意識 } \\
\text { 低下, 脱力, 心音不正, 血圧降下 }\end{array}$ & $\begin{array}{l}\text { 初回 } 240 \mathrm{cc} 2 \cdot 3 \text { 回 } \\
100 \mathrm{cc} \text { 計 } 440 \mathrm{cc}\end{array}$ & 血压回復, 意識回復, 体力增強 \\
\hline 8.6 & 1 & 衝 & 撃 & $\begin{array}{l}\text { 自動車衝突による腹部内出血, 意識 } \\
\text { 不明, 虚脱, 血圧降下 }\end{array}$ & $\begin{array}{l}\text { 初回 } 300 \mathrm{cc} 2 \cdot 3 \cdot 4 \\
\text { 回 } 120 \mathrm{cc} \text { 計 } 660 \mathrm{cc}\end{array}$ & 血圧回復, 心音・脈搏好転, 意識回 \\
\hline 5.2 & 1. & 手術出 & & $\begin{array}{l}\text { 断脚手術中出血多量, 血生降下, 脈 } \\
\text { 搏消失, 呼吸異状, }\end{array}$ & $\begin{array}{l}\text { 初回 } 120 \mathrm{cc} 2 \cdot 3 \text { 回 } \\
80 \mathrm{cc} \text { 計 } 280 \mathrm{cc}\end{array}$ & 血圧回復, 心音・脈搏 - 呼吸好転 \\
\hline & 3 & 難 & 産 & $\begin{array}{l}\text { 難産, 分娩時間延長, 脱力, 心音不 } \\
\text { 正, 脈搏 - 呼吸異状 }\end{array}$ & $\begin{array}{l}\text { 初回 } 120 \mathrm{cc} 2 \cdot 3 \text { 回 } \\
80 \mathrm{cc} \text { 計 } 280 \mathrm{cc}\end{array}$ & 体力回復, 心音 - 脈搏 - 呼吸好転 \\
\hline
\end{tabular}

日獣会誌 15 (1962) 
は皆無であるといって差支えない，乙かし低蛋白症のご とく血圧に異常のないものに対し大量のプラズマを急速 に輸液したような場合には輸液ショックをたまたま起こ すことがある。このような場合には呼吸異常と心搏数, 脈搏に異常を呈するので悪心, 痤攣, 浮腫, 心音不正, 不正脈などの発現が見られるから輸液実施中常に十分全 身症状に注意して観察し, これらの異常を認めた際は直 ちに輸液を中止すべきである。また過剩輸液の場合は顔 面に浮腫を呈したり，あるいは全身浮腫を呈することも あるが，多くの場合一過性のものであるので輸液を中止 すれば消失する。この輸液に上る肝機能障害の発生は起 こさず尿中に蛋白の排泄る認められないしアナフィラキ シーを起こすこともない。また人のプラズマ輸液で警戒 されている急性肝炎に対しても犬のプラズマ輸夜では, プラズマは完全に滅菌されているので全く感染性の肝炎 発現の恐れはないと見做される，従って輸液量および輸 液速度に誤りがなければ副作用は注とんどない。

$$
\text { 文献 }
$$

1）松葉, 広江：陸軍獣医団報 209, 1095 (1926). 2) Orson, W.H. : Abst. No. Am. Vet., 22 (1941). 3) Robertson, H.J.: J.A.V.M.A., 98 (1941). 4) Levinson, S.O., Weston, R.E. Janata, M. \& Necheles, H. : Surgery, 12, 878 (1942). 5) Swingle, W.W., Remington, J.W., Kleinberg, W., Drill, V.
A. \& Eversoll, W.J.; Am. J.Physiol., 138 (1942). 6) Ebert, R.V.: Stead, E.A., JR., Warren, J.N., and Watts, W.E.: Am. J. Physiol., 136 (1942). 7) Strumia, M.M. \& McGraw, J.J.JR. : Ann. Int. Med., 15, 80 (1941). 8) A.S. Wiener: Blood group and Blood Transfusion (1945).99) 古畑: 血液学, 昭22

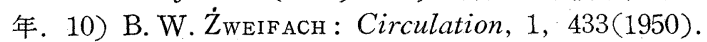

11) 橴沢：ショックの臨床, 昭24年. 12) Young, L.E., ERvin, D.M., \& Yuile, C.L. : Blood, 4, (1949). 13) Lenahan, N.E., Spitz, F.A. \& Metcalf, D. : Arch. Surg., 57, 3， 435 (1948). 14) 河石：日本外 科学誌, 51, 67 (1950). 15) - : 臨床, 5(1)(1952). 16) 加藤：輸血学 (1951). 17) 福田, 涉沢 : 輸血の 臨床, 昭和 27 年. 18)-, 一 : 外科と栄養, 昭和 27 年. 19) 内藤：外科学研究の進歩, 第 5 集, 昭和 32 年. 20 ) 藤田：血嶈蛋白の蹦床, 昭和 31 年.

21）北, 外: 麻布獣医科大学研究報告, No.3 (1956), No.4 (1957), No.5 (1958), No.6(1959), No.8 (1960). 22) Young, L.E. : Obrien, W.A., Swisher, S.N., Miller, G. \& Yuille, C.L. : Am.J. Vet. Research, 13, (1952)。23) 細田, 外: 畜産の研究8, 10, 194. 24) Coockson, B.A., Costas-Durieux, J. \& Bailey, C.P. : Am. Surg., 139, Apr. (1954). 25) 雨宮: 輸 血, 輸液の常識, 昭和 31 年. 26) 紊藤：臨床外科, 8 , 383-387（1953). 27) 村上：血液と輸血，1（3）208225 May (1954).

\section{ミンクのトキソプラズマ症}

4,000 頭に達するミンクを飼育している農場で，1961 年の10月の終り頃から10週間にわたって1疾病が発生し 多くのミンクが次タと死亡した，この病気はすべての年 令のミンクに発生した，大部分の症例は衰弱して死亡し たが，急死したものも少数例存在した，症例のいずれに も神経症状は認められなかった。死亡例36頭の剖検所見 としては, 重度の腎炎が主な変化であったが Aleutian 病を思わせる病変も数例飞認められた。

これらのミンクに与兊られていた慨はブロイラ一屑 25 $\%$, 魚 $35 \%$, 肝 $5 \%$, 款物 $30 \%$ ，イース卜 $1 \%$ ，草粉末 $1 \%$,大豆粉末 $1 \%$ それに羊の頭を加えたものであった。

1962年の 1 月にブロイラー屑を慨から除いたところ, 死亡するるのがなくなった。

1961年12月11日に外見上正常なミンク24頭から血清を とり dye test法により血清中のトキップラズマに対する 抗体を検索した。その結果く1:16が11頭(45.8\%), $1: 16$ 〜 : 63 が 3 頭(12.5\%), 1: 64 1:255が 8 頭(33.3\%), $>1: 256$ が 2 頭 (8.3\%) であった。1962年 1 月 22 日に 外見上正常なミンク10頭を殺し，その脳乳刋を各 4 匹つ つのマウスの皮下に注射してトキップラズマの存在を検 索したところ，10頭中 3 頭が陽性であった。

(W.A. Watson et al., Vet. Rec., 74, 1027 1962)

\section{訂正}

先月号（第15巻第11号）の解説記事中に埕りがありま したので下記の通り訂正いたします。

\begin{tabular}{|c|c|c|c|c|}
\hline \multirow{3}{*}{ 468頁 } & \multirow{2}{*}{\multicolumn{2}{|c|}{ 右段上から 4 行目 }} & \multirow{2}{*}{$\begin{array}{c}\text { 誤 } \\
4 \%\end{array}$} & \multirow{2}{*}{$\begin{array}{c}\text { 正 } \\
6 \%\end{array}$} \\
\hline & & & & \\
\hline & " & 5 行目 & $0.48 \mathrm{~g}$ & $0.96 \mathrm{~g}$ \\
\hline & " & 28 行目 & $4 \%$ & $6 \%$ \\
\hline & " & 29 行目 & $6 \%$ & $8 \%$ \\
\hline 470頁 & 左段上 & 4 行目 & $10 \%$ & $3 \sim 5 \%$ \\
\hline
\end{tabular}

\section{獣原師古求む！}

1. 昭和 30 年以降大学卒の独身男子

2. 東京都内 獣医畜産用薬品・資材専門 の有力会社

3. 職務 商品開発課または販売課

4. 給与 面談時決定(往復旅費支給)

5. 独身者寮, 健保, 労保, 失保, 年金, 退職 金制度あり

6. 書類選考のら光面接日通知します

7. 自筆履歴書, 身上調書, 写真を日本獣医 師会私書函第 1 号あて急送されたい 